\title{
Spatial and temporal plant phenological niche differentiation in the Wadi Degla desert ecosystem (Egypt)
}

\author{
Ahmad K. Hegazy ${ }^{1 *}$, Abdelrahman A. Alatar ${ }^{1}$, Jon Lovett-Doust ${ }^{2}$, \\ HOSAM A. EL-ADAWY ${ }^{3}$ \\ ${ }^{1}$ Department of Botany and Microbiology, College of Science, King Saud University, \\ Riyadh 11451, P.O. Box 2455, Saudi Arabia \\ ${ }^{2}$ Department of Biological Sciences, University of Windsor, Windsor, Ontario, Canada \\ ${ }^{3}$ Natural Resources Surveying Department, Environmental Studies and Research Insti- \\ tute, Minofiya University, Sadat City, Egypt
}

\begin{abstract}
Twenty dominant plant species representing different life forms were investigated phenologically over a period of 36 months (January 2004 to December 2006). Plant populations were sampled at down-, mid-, and upstream sites in a desert wadi ecosystem. The results were analyzed using TWINSPAN, DCA and CCA techniques. Five phenological niches were apparent: (1) species flowering all year round, with peaks in spring and autumn such as Ochradenus baccatus; (2) species flowering during winter including Lycium shawii and Tamarix nilotica; (3) species flowering during spring, e.g., Zilla spinosa, Zygophyllum coccineum and Capparis spinosa; (4) species flowering during summer including Iphiona mucronata and Deverra triradiata; and (5) species flowering during autumn that include Atriplex halimus and two Anabasis species. The climatic variables, including temperature, rainfall and relative humidity, affect the phenological niches and between-species differences. Within-species variations occurred between years and there were no between-site variations for most study species. The different plant species exhibited phenological diversity along the course of the wadi ecosystem. The phenological niches are species-specific and environmentally dependent rather than local selective pressures.
\end{abstract}

Keywords: Desert, environment, flowering, Egypt, life forms, phenology, niche

\section{Introduction}

Whereas an understanding of plant phenology may be best interpreted in the context of the larger flowering community (AUGSPURGER 1983), there have been few studies that ex-

* Corresponding author permanent address: Botany Department, Faculty of Science, Cairo University, Giza, Egypt. e-mail: akhegazy@yahoo.com

Copyright ${ }^{\circledR} 2012$ by Acta Botanica Croatica, the Faculty of Science, University of Zagreb. All rights reserved. 
amined patterns among or within species (GOULART et al. 2005). Few studies have compared species located at sites having marked environmental differences (BORCHERT 1980, LOBO et al. 2003, VITASSE et al. 2009). A comparative approach is useful for understanding the phenological rhythm as a species survival strategy, and showing how abiotic factors may generate differentiation among species in their phenology. The extent of synchrony between phenological and ecological events is often shown by the correlation of population sizes at different localities, where synchrony tends to decrease with distance (HUDSON and KEATLEY 2010).

Wadi vegetation dynamics as a whole and plant phenologies in particular have been little studied, especially following the episodic flash floods that characterize these ephemeral watercourses. In the desert, plant growth is almost always triggered by rainfall, and hence occurs infrequently or irregularly during rain. Vegetation tends to develop in wadis and other habitats receiving runoff water. Given that rainstorms do not follow precise annual patterns, and there are frequently decades between storm events, the perennial plant seasonal phenologies are products of the whole environmental setting, and thus tend to have great variability and variation in response (KASSAS 1966).

Desert plants often exhibit phenotypic plasticity in their ability to adjust the timing of phenological events to accommodate differences in habitat, microsite and other variations in local environmental factors (AYYAD et al. 1985, GuNSTER 1994, GHAZANFAR 1997). Phenological records on desert plants can be used as environmental indicators to determine the length of the actual growing season, where plants may compete for an advantage. The phenological phases of plants within different environmental conditions may explain how desert species are adapted to, and often restricted by, particular local conditions, and how plant life cycles are adjusted in accordance with environmental stressors. This approach can be used to explain features in a plant population or community that must change for survival and growth under a given set of environmental conditions (SEGHIERI and SIMIER 2002, GOULART et al. 2005).

The phenology of 54 desert plants in a gravel desert wadi in northern Oman was studied by GHAZANFAR (1997) in relation to climatic variables. The onset and duration of growth and flowering were significantly associated with the timing and abundance of rainfall, as was plant growth form. The variation in total rainfall did not affect the onset of flowering in phanerophytes and chamaephytes due to their adaptive perennial habit and water availability in the extended rhizosphere. Alternatively, due to their ephemeral habit, the phenology of therophytes and geophytes was significantly affected by variations of rainfall. Despite the differences in timing and amount of rainfall, the sequence of flowering for the majority of species was more or less constant among years.

MARCO et al. (2000) studied three populations of Larrea divaricata in dry Chaco systems, in Argentina, and showed that patterns of flowering and fruiting in especially heterogeneous habitats differed significantly among populations of a single species. AYYAD et al. (1985) studied phenology in eight desert perennials having different life forms, in the non-saline depressions of the Western Mediterranean coastal region. They found major effects of climatic fluctuation and of controlled grazing on the phenology in these plants. Recently, LESICA and KITTELSON (2010) suggested that studies have only just begun to document phenological changes and their relationship to climate change. Phenological studies at vegetation-level are scarce in arid lands, which are likely early indicators of climate 
change. Previous studies on plant-environment relationships have demonstrated that population dynamics and phenological events are considered good indicators of the bioclimatic character in desert regions (Shaltout 1987, Hegazy 1990, ÅgREN et al. 2008).

In this study we argue that hyperarid desert wadi conditions may lead to phenological specialization and diversity, including temporal partitioning of the flowering and reproductive niche around the year in both space and time. Phenological specialization may be a product of competition among plants for pollinators and pollination activities, and we expect, in principle, some evolutionary divergence along a resource axis (i.e., resource partitioning), reducing the negative interaction between coexisting species. STONE et al. (1998) studied partitioning of pollinators during flowering in an African Acacia community. They showed major functional partitioning was achieved among some Acacia species through separation of flowering in space and seasonal time, and through inter-specific differences in pollinator guilds.

The aim of this paper is to examine whether there are different phenological patterns among the different plant populations in a desert wadi ecosystem and, whether the phenology of the different plant species is constrained by local selective pressure and whether it is to any extent influenced by the climatic variables.

\section{Material and methods}

Wadi Degla is located in the north of the Eastern Desert of Egypt. It extends some 30 kilometres in a southeast to northwest direction, between longitude $31^{\circ} 19^{\prime}$ to $37^{\prime}$ and latitude $29^{\circ} 53^{\prime}$ to $57^{\prime}$. The Wadi has a significant gradient, dropping $c .10 \mathrm{~m} \mathrm{~km}^{-1}$ along the course of the stream, and draining from Gabal (Mountain) Abu Shama, at $578 \mathrm{~m}$ a.s.l. and debouching into the Nile Valley, at $21 \mathrm{~m}$ a.s.l. (Fig. 1). The study sites of the wadi differ in elevations, with the downstream section ranging from 85 to $200 \mathrm{~m}$ a.s.l., midstream from 220 to $330 \mathrm{~m}$ a.s.l., upstream from 340 to $420 \mathrm{~m}$ a.s.l., and the (downstream) tributaries from 140 to $250 \mathrm{~m}$ a.s.l. The main wadi is generally wide, though differs in its width among the four locations between 50 to $600 \mathrm{~m}$.

The highest values of rainfall in the study site are $25.3 \pm 14.23 \mathrm{~mm}$, relative humidity $64.37 \pm 5.54 \%$, temperature $27.66 \pm 1.2^{\circ} \mathrm{C}$ and wind speed $15.71 \pm 5.1 \mathrm{Km} \mathrm{h}^{-1}$. The lowest values of temperature are $16.63 \pm 4.44{ }^{\circ} \mathrm{C}$, dew point $8.74 \pm 2.7$, relative humidity $47.27 \pm 0.01 \%$ and wind speed $11.14 \pm 0.44 \mathrm{Km} \mathrm{h}^{-1}$ with absence of rainfall.

Wadi Degla is an ancient and steep limestone valley in Egypt's Eastern Desert. In 1999, the down- and midstream part of Wadi was declared a protected area (Fig. 1). The soil inWadi Degla is mostly composed of rock waste varying in texture from silt to gravels and boulders. The bed of the wadi is covered with layers of differing textures, influencing water availability (HASSAN 2002). Aridity prevails throughout the area: low and irregular rainfall, sharp diurnal changes of temperature and atmospheric humidity. The array of major climatic variables is collected at the local Helwan Climate Station for the study period of 2004-2006 (Tab. 1). The wettest year was 2004 and 2006 the driest. Analysis of the rainfall data for period 1998-2007 (TRMM, Tropical Rainfall Measurement Data 2007, EL-GAMAL et al. 2008) demonstrate the hyperaridity and severe scarcity of rainfall over the Wadi Degla ecosystem. The total accumulated depth of rainfall varies from $100 \mathrm{~mm}\left(c .10 \mathrm{~mm}_{\text {year }}{ }^{-1}\right)$ in the eastern (upstream) region of the catchment area to more than $400 \mathrm{~mm}\left(c .40 \mathrm{~mm} \mathrm{year}^{-1}\right)$ 


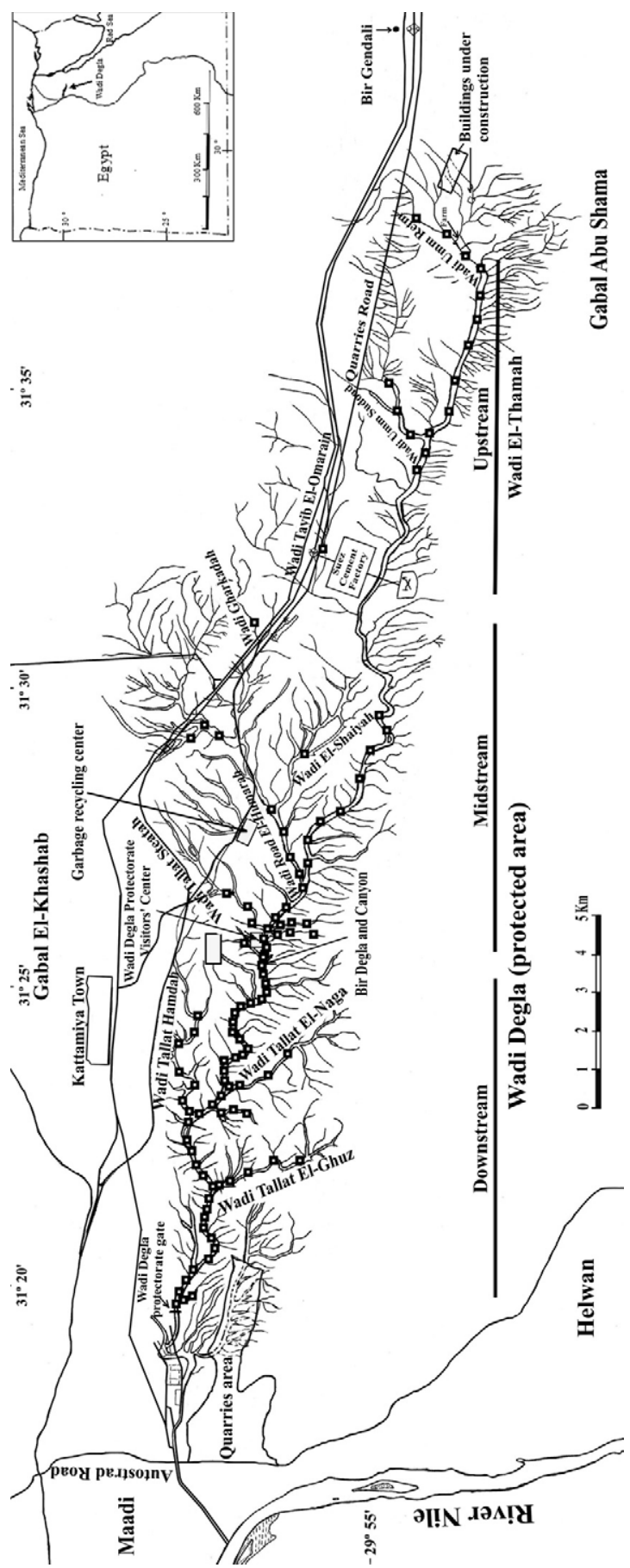

Fig. 1. Map showing the location of Wadi Degla (Wadi Degla down- and midstream (protected Area) and Wadi El-Thamah that represents Wadi Degla upstream) and its tributaries. Plots sampled for study are represented by black squares. 
Tab. 1. Monthly average temperature, relative humidity (\%), wind speed $\left(\mathrm{km} \mathrm{h}^{-1}\right)$, wind direction (degrees from North) and dew point $\left({ }^{\circ} \mathrm{C}\right)$ at Helwan station during the field study years 2004-2006 (Data source from Egyptian Meteorological Organization). Accumulated rainfall $\left(\mathrm{mm}\right.$ month $^{-1}$ ) calculated according to Tropical Rainfall Measurement Mission technique (EL-GAMAL et al. 2008).

\begin{tabular}{|c|c|c|c|c|c|c|}
\hline Month/ Year & $\begin{array}{l}\text { Rainfall } \\
(\mathrm{mm})\end{array}$ & $\begin{array}{c}\text { Temperature } \\
\left({ }^{\circ} \mathrm{C}\right)\end{array}$ & $\begin{array}{c}\text { Relative } \\
\text { humidity } \\
(\%)\end{array}$ & $\begin{array}{c}\text { Wind } \\
\text { Speed } \\
\left(\mathrm{km} \mathrm{h}^{1}\right)\end{array}$ & $\begin{array}{c}\text { Wind } \\
\text { Direction } \\
\left(^{\circ}\right)\end{array}$ & $\begin{array}{l}\text { Dew } \\
\text { Point } \\
\left({ }^{\circ} \mathrm{C}\right)\end{array}$ \\
\hline Jan-2004 & 27 & 11.9 & 70.6 & 21.5 & 202 & 6.36 \\
\hline Feb-04 & 6 & 15.9 & 58.9 & 9.4 & 66 & 7.44 \\
\hline Mar-04 & 8 & 19.2 & 54.1 & 13.9 & 109 & 8.78 \\
\hline Apr-04 & $<1$ & 20.9 & 50.6 & 14.1 & 70 & 8.50 \\
\hline Мay-04 & $<1$ & 25.3 & 51.6 & 14.1 & 93 & 12.18 \\
\hline Jun-04 & 0 & 26.8 & 47.2 & 11.4 & 135 & 12.41 \\
\hline Jul-04 & 0 & 28.5 & 47.2 & 10.8 & 146 & 14.35 \\
\hline Aug-04 & $<1$ & 28.2 & 51.9 & 10.5 & 149 & 14.94 \\
\hline Sep-04 & 2 & 26.0 & 54.6 & 12.6 & 126 & 13.89 \\
\hline Oct-04 & 3 & 24.6 & 57.4 & 11.5 & 89 & 13.52 \\
\hline Nov-04 & 39 & 20.6 & 62.1 & 12.2 & 122 & 11.67 \\
\hline Dec-04 & 10 & 17.3 & 60.3 & 13.2 & 92 & 8.19 \\
\hline Annual total & 96 & & & & & \\
\hline Annual mean & 8 & & & & & \\
\hline Jan-2005 & 8 & 13.5 & 66.3 & 18.0 & 177 & 6.18 \\
\hline Feb-05 & 15 & 14.1 & 58.1 & 13.5 & 157 & 4.90 \\
\hline Mar-05 & 5 & 18.2 & 56.4 & 12.9 & 116 & 7.00 \\
\hline Apr-05 & 20 & 21.7 & 45.3 & 16.5 & 142 & 8.02 \\
\hline May-05 & $<1$ & 25.2 & 47.6 & 14.0 & 102 & 12.22 \\
\hline Jun-05 & $<1$ & 27.7 & 46.2 & 11.5 & 124 & 14.44 \\
\hline Jul-05 & 0 & 30.9 & 49.4 & 10.4 & 152 & 17.66 \\
\hline Aug-05 & 0 & 30.8 & 54.6 & 10.7 & 121 & 18.76 \\
\hline Sep-05 & 0 & 27.2 & 52.4 & 11.1 & 139 & 16.10 \\
\hline Oct-05 & 0 & 24.1 & 59.0 & 11.5 & 139 & 15.24 \\
\hline Nov-05 & 1 & 18.7 & 57.1 & 10.6 & 126 & 10.03 \\
\hline Dec-05 & 2 & 16.1 & 56.2 & 12.1 & 126 & 7.84 \\
\hline Annual total & 52 & & & & & \\
\hline Annual mean & 4 & & & & & \\
\hline Jan-2006 & 3 & 14.8 & 55.3 & 8.8 & 142 & 6.10 \\
\hline Feb-06 & 5 & 15.8 & 52.1 & 11.9 & 142 & 5.97 \\
\hline Mar-06 & 6 & 19.4 & 47.7 & 11.6 & 143 & 7.60 \\
\hline Apr-06 & 2 & 22.3 & 51.6 & 11.8 & 100 & 8.10 \\
\hline May-06 & $<1$ & 25.1 & 98.5 & 12.0 & 57 & 8.59 \\
\hline Jun-06 & 0 & 28.0 & 39.5 & 13.4 & 106 & 12.59 \\
\hline Jul-06 & 0 & 29.6 & 43.4 & 10.3 & 196 & 15.14 \\
\hline Aug-06 & 0 & 31.8 & 48.8 & 10.3 & 127 & 17.93 \\
\hline Sep-06 & $<1$ & 28.6 & 51.9 & 10.9 & 96 & 16.56 \\
\hline Oct-06 & 0 & 25.8 & 54.4 & 8.9 & 162 & 15.28 \\
\hline Nov-06 & 1 & 18.0 & 57.7 & 9.0 & 183 & 9.58 \\
\hline Dec-06 & 1 & 13.4 & 58.0 & 9.7 & 161 & 5.64 \\
\hline Annual total & 20 & & & & & \\
\hline Annual mean & 2 & & & & & \\
\hline
\end{tabular}


in the downstream, western part of the catchment area, near the outlet, while it ranged between 200 to $250 \mathrm{~mm}$ (c. 20-25 mm year ${ }^{-1}$ ) in the midstream locations. The total accumulated ten-year depth of rainfall of the three downstream tributaries varied from $250 \mathrm{~mm}$ to $350 \mathrm{~mm}$ (in the west), according to position (Fig.1).

For phenological observations, a total of $114(10 \times 10 \mathrm{~m})$ permanent plots were placed at the three sampling sites (down-, mid- and upstream) along Wadi Degla stream. Population phenology of the dominant twenty perennial species present at one or more site was investigated. These constituted the major components of the wadi vegetation (EL-ADAWY 2011), and represented an array of different life forms (Tab. 2). Species identification followed Boulos (1999-2005).

Tab. 2. Major species represented in populations at Wadi Degla habitats. $\mathrm{Ch}$-chamaephyte (subshrub); $\mathrm{Nph}$ - nano-phanerophyte (shrub); $\mathrm{Ph}$ - phanerophyte (tree); +- present; - - absent

\begin{tabular}{lccccc}
\hline \multicolumn{1}{c}{ Species } & \multicolumn{3}{c}{ Habitat type } & Life \\
\cline { 2 - 5 } & Down-stream & Mid-stream & Up-stream & form \\
\hline Agathophora alopecuroides (Chenopodiaceae) & + & + & - & $\mathrm{Ch}$ \\
Anabasis articulata (Chenopodiaceae) & - & + & + & $\mathrm{Ch}$ \\
Anabasis setifera (Chenopodiaceae) & + & + & - & $\mathrm{Ch}$ \\
Atriplex halimus (Chenopodiaceae) & + & + & + & $\mathrm{Nph}$ \\
Capparis spinosa (Capparaceae) & + & + & - & $\mathrm{Ch}$ \\
Cocculus pendulus (Menispermaceae) & - & + & - & $\mathrm{Ph}$ \\
Deverra tortuosa (Apiaceae) & + & - & + & $\mathrm{Ch}$ \\
Deverra triradiata (Apiaceae) & + & + & - & $\mathrm{Ch}$ \\
Echinops spinosus (Asteraceae) & + & - & - & $\mathrm{Ch}$ \\
Ephedra aphylla (Ephedraceae) & + & - & - & $\mathrm{Nph}$ \\
Fagonia mollis (Zygophyllaceae) & - & + & - & $\mathrm{Ch}$ \\
Farsetia aegyptia (Brassicaceae) & + & + & - & $\mathrm{Ch}$ \\
Gymnocarpos decandrus (Caryophyllaceae) & + & - & - & $\mathrm{Ch}$ \\
Iphiona mucronata (Asteraceae) & + & + & - & $\mathrm{Ch}$ \\
Lycium shawii (Solanaceae) & + & + & + & $\mathrm{Ph}$ \\
Ochradenus baccatus (Resedaceae) & + & + & - & $\mathrm{Nph}$ \\
Retama raetam (Fabaceae) & - & + & + & $\mathrm{Nph}$ \\
Tamarix nilotica (Tamaricaceae) & - & + & - & $\mathrm{Nph}$ \\
Zilla spinosa (Brassicaceae) & + & + & + & $\mathrm{Ch}$ \\
Zygophyllum coccineum (Zygophyllaceae) & + & + & - & $\mathrm{Ch}$ \\
\hline
\end{tabular}

Phenological observations of individuals of each population were recorded on 50 marked and randomly selected individual plants. When there were fewer than 50 individuals in a population, observations were made on all individuals available in that population. Periodic observations of phenological phases were carried out every 10 days in the peak growing season (spring), or monthly in other seasons, during three consecutive years (2004 to 2006). Phenological phases were defined on a scale from 1 to 6 called the phenology in- 
dex. These phases were: $1=$ vegetative, $2=$ flower buds, $3=$ flowering, $4=$ fruiting, $5=$ seed dispersal and $6=$ senescence or dormancy (HEGAZY and EesA 1991). The mean value of phenological index for individuals of different plant sizes was determined for each location per month. Within each population, an individual was recorded when visual estimation indicated that at least $25 \%$ of the canopy had reached a particular phase.

The classification technique known as two-way indicator species analysis (TWINSPAN) (HILL 1979) was used to analyze the plant phenological traits, using the community analysis package (CAP 2002). TWINSPAN was used to separate the phenological traits of the different species into groups. Ordination techniques were performed by using detrended correspondence analysis (DCA), community analysis package (CAP) and canonical correspondence analysis (CCA) (TER BRAAK and ŠMILAUER 2002). DCA was performed to allow overall assessment of variance between the different phenological groups obtained from TWINSPAN. CCA was used for showing the relation between the phenological groups and environmental variables. TWINSPAN, DCA and CCA were based on the phenological index (PI) of the twenty species at different sites across the twelve months of 2004, which was representative in regard to temperature, and also the rainiest of the three years of observation. The ordination using CCA at the population level (site) gave similar results and is not reported here (see EL-ADAwY 2011).

Data used in the classification and ordination of population phenology are spatially based and considered as different values of phenological index in different species at different sites. Yet these data were also temporal in nature. Here, sites were represented by month, environmental variables by six climatic factors (collected at the local Helwan Climate Station near the study area) and the phenological index was considered according to the number of sites where the species occurred. Thus phenological index was considered as a temporal index that changed with time (monthly) and space (site) along the wadi.

Shannon-Wiener diversity index $\left(\mathrm{H}^{\prime}\right)$ was calculated to measure the flowering phenology of the twenty plant species throughout 2004-2006, following LUDWIG and REYNOLDS (1988).

Analysis of variance (ANOVA) (SPSS 15 for Windows) was used to test the variation in phenological traits of the study species according to population locality (down- vs. mid- vs. upstream) and year (2004 vs. 2006) as sources of variation.

\section{Results}

\section{Phenological diversity}

According to the time of flowering and fruiting, four plant phenological groups are derived from TwINSPAN classification (Fig. 2). Group A covered the three months November to January, here called the winter season. This group includes populations of Lycium shawii and Tamarix nilotica. Group B included the three months August to October, which approximates the autumn season. Populations of the four species Agathophora alopecuroides, Anabasis articulata, Anabasis setifera and Atriplex halimus are included in this group. Group C comprised the four months February to May, representing the spring season. This group contains populations of Capparis spinosa, Cocculus pendulus, Deverra tortuosa, Echinops spinosus, Ephedra aphylla, Fagonia mollis, Farsetia aegyptia, Gymnocarpos decandrus, Ochradenus baccatus, Retama raetam, Zilla spinosa and Zygophyllum 
Hegazy A. K., Alatar A. A., Lovett-Doust J., El-Adawy H. A.

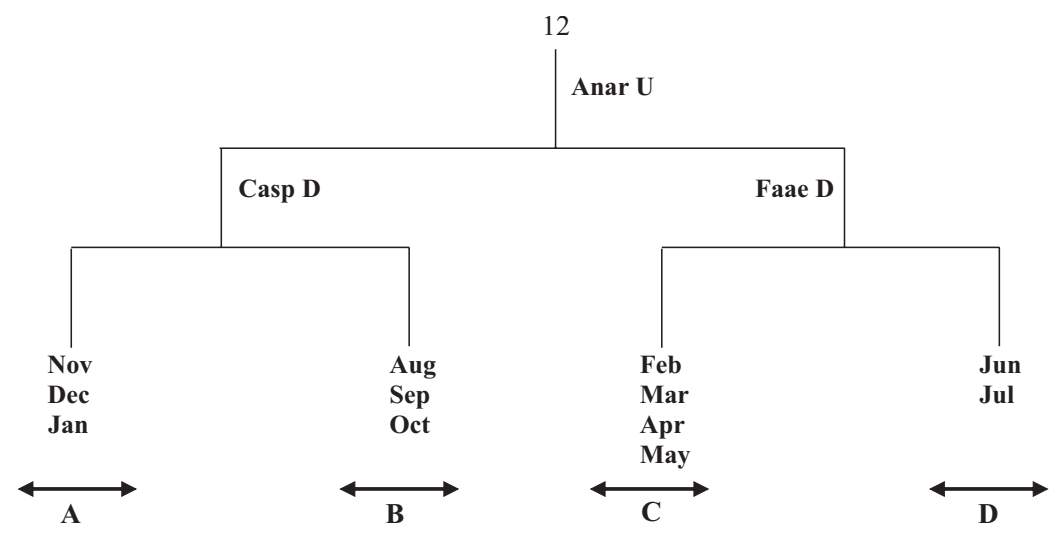

Fig. 2. Dendrogram of 12 months based on phenological index of twenty species in different populations in Wadi Degla. Four phenological groups are defined from the TWINSPAN technique (A, B, C, D). Indicator species are abbreviated to the first two letters of both genus and species followed by capital letter representing habitat (population) (D - downstream; $\mathrm{M}$ midstream; U - upstream). Distribution of species demonstrated through DCA diagram.

coccineum. The last group, $\mathrm{D}$, represents the hot summer season covering the two months June and July. This group was characterized by populations of Deverra triradiata and Iphiona mucronata.

The DCA ordination diagram of the different populations of the twenty species around the year (Fig. 3) demonstrated the segregation of four phenological groups, which repre-

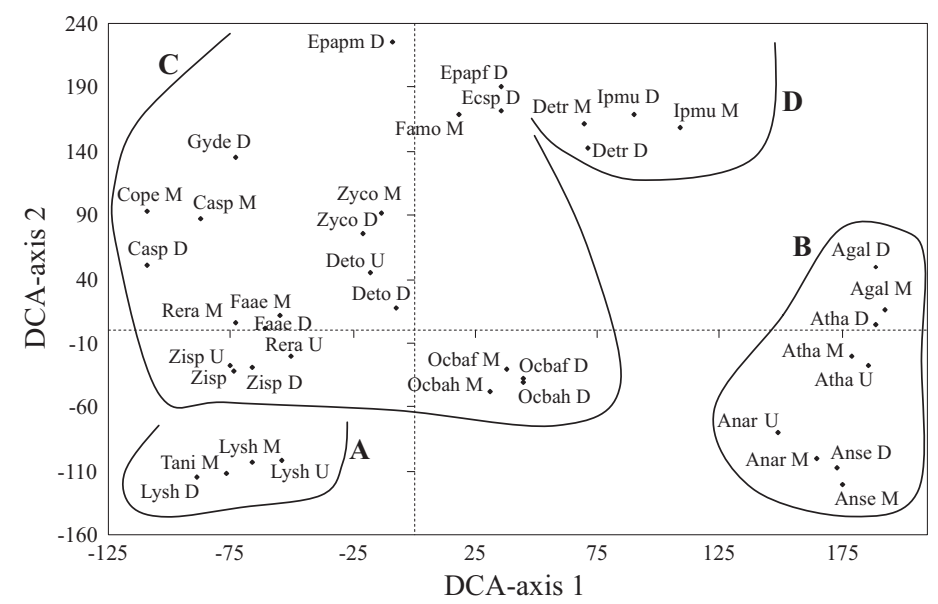

Fig. 3. DCA ordination of species in different populations in 12 months with phenological groups defined from TWINSPAN classification. Species which flower and fruit in autumn, summer, spring and winter are further separated by the appearance of a fifth pattern of $O$. baccatus. Indicator species are abbreviated to the first two letters of both genus and species followed by capital letter representing habitat (population) ( $\mathrm{D}$ - downstream; $\mathrm{M}$ - midstream; $\mathrm{U}$ - upstream). The fifth letter for E. aphylla and O. baccatus, $\mathrm{m}=$ male, $\mathrm{f}=$ female, $\mathrm{h}=$ hermaphrodite. 
sent four phenological events. Populations of species in group A represent a phenological event characterized by flowering in winter months, which are characterized by the lowest temperature and highest rainfall and relative humidity values (Tab. 1). Species in group D flower in the summer months, characterized by the highest temperature, almost no rainfall and the lowest humidity values. Different populations of species of group B represent a phenological group characterized by flowering in autumn. Most of the populations of the species included in group $\mathrm{C}$ represent the most typical phenological group, characterized by flowering during the spring. Months of groups B and $\mathrm{C}$ were characterized by intermediate values of temperature, rainfall and relative humidity.

Populations of female and hermaphrodite Ochradenus baccatus took a particular location at the middle and lower side of the ordination diagram (Fig. 3), that lying between spring and autumn groups, flowering across most of the year, with two peaks, in spring and autumn, representing the fifth phenological group. E. aphylla, E. spinosus and F. mollis flower in spring, with some individuals delaying, and starting flowering at the beginning of summer. Alternatively, some individuals of $D$. triradiata and I. mucronata may not flower until the end of spring. Populations of L. shawii and T. nilotica typically flowered in late winter and early spring. A. alopecuroides populations (group B) are located at the upper part of the array and near group $\mathrm{D}$, and flower in late summer.

The twenty species represent 18 genera and 13 families and showed inter-specific variation in the relative timing of the phenological phases during 2004 and 2006. For example, the five species, A. halimus, D. tortuosa, D. triradiata, $R$. raetam and I. mucronata showed no difference between years, while the six species A. alopecuroides, D. tortuosa, $D$. triradiata, $F$. aegyptia, $R$. raetam and $Z$. coccineum differed significantly in phenophases among the three study sites. Female and male individuals of E. aphylla showed significant phenological variations. Some species exhibited vegetative activity throughout the entire rainy year 2004, including $O$. baccatus and $C$. pendulus, while others persisted in vegetative activity for periods between 6 months (e.g., E. spinosus) and 11 months (e.g., $C$. spinosa). Reproductive activity extended across the entire year in some species, with bimodal peaks in flowering and fruiting, e.g., O. baccatus, or it may extend across most months of the year, e.g., C. pendulus and D. tortuosa). Most species exhibited reproductive activity during a period of two to four months with a unimodal peak of flowering and fruiting.

\section{Phenology - environment relationship}

The environmental variables representing different phenological groups all over the year are shown in table 3 . There is significant variation among the major four phenological groups in response to rainfall, temperature, relative humidity and dew point. Species in group A are phenologically active through the winter season, while group D species are active in the summer months. The remaining groups $\mathrm{B}$ and $\mathrm{C}$ are phenologically active in autumn and spring.

The correlation between phenological dormancy or senescence and climatic variables is shown in the ordination diagram produced by CCA with biplot of the environmental variables (Fig. 4). The length and direction of an arrow representing a given environmental variable provide an indication of the importance and direction of the gradient of environmental variable change. The angle between, an arrow and each axis is a reflection of the de- 
Hegazy A. K., Alatar A. A., Lovett-Doust J., El-Adawy H. A.

Tab. 3. Environmental variables of the different phenological groups obtained by TWINSPAN classification in Wadi Degla. Values are means followed by standard deviation. Significance is according to ANOVA $(\mathrm{P} \leq 0.05), \mathrm{ns}=$ non significant

\begin{tabular}{lccccc}
\hline \multirow{2}{*}{ Environmental variable } & \multicolumn{5}{c}{ Phenological group } \\
\cline { 2 - 5 } & $\mathrm{A}$ & $\mathrm{B}$ & $\mathrm{C}$ & $\mathrm{D}$ & \multirow{2}{*}{ Significance } \\
\hline Rainfall $(\mathrm{mm})$ & $25.3 \pm 14.2$ & $1.4 \pm 1.3$ & $3.8 \pm 4.0$ & $0 \pm 0$ & $<0.05$ \\
Temperature $\left({ }^{\circ} \mathrm{C}\right)$ & $16.6 \pm 4.4$ & $26.3 \pm 1.8$ & $20.3 \pm 3.8$ & $27.6 \pm 1.2$ & $<0.05$ \\
Relative humidity $(\%)$ & $64.3 \pm 5.5$ & $54.6 \pm 2.7$ & $53.8 \pm 3.6$ & $47.2 \pm 0.01$ & $<0.01$ \\
Wind speed $\left(\mathrm{km} \mathrm{h}^{-1}\right)$ & $15.7 \pm 5.0$ & $11.5 \pm 1.0$ & $12.9 \pm 2.3$ & $11.1 \pm 0.4$ & $\mathrm{~ns}$ \\
Wind direction $\left({ }^{\circ}\right)$ & $138.8 \pm 56.8$ & $122.0 \pm 30.6$ & $85.0 \pm 20.1$ & $140.9 \pm 8.3$ & $\mathrm{~ns}$ \\
Dew point $\left({ }^{\circ} \mathrm{C}\right)$ & $8.7 \pm 2.7$ & $14.1 \pm 0.7$ & $9.2 \pm 2.0$ & $13.3 \pm 1.3$ & $<0.05$ \\
\hline
\end{tabular}

gree of correlation with the axis. By dropping a perpendicular to the arrow from each species-point an indication is provided of the relative position of species along the variable gradient. Temperature, dew point, relative humidity and rainfall were the major climatic variables exhibiting significant correlations with the first two axes of the analysis (Tab. 4, Fig. 4). Species of groups A and C flower in winter, spring and come to dormancy in the hot season. In contrast, species of group D, I. mucronata and D. triradiata which flower in the hot season and become senescent in the wet season, are present on the high gradient of rainfall and relative humidity and low gradient of temperature and dew point (see the arrow length in Fig. 4).

Species of group B, characterized by flowering in autumn and senescence in winter and spring seasons, are present on an intermediate gradient of rainfall and relative humidity and

Tab. 4. Results of CCA and correlation coefficient of the six parameters with the first four CCA axes.

\begin{tabular}{lccccc}
\hline Axes & 1 & 2 & 3 & 4 & $\begin{array}{c}\text { Total } \\
\text { inertia }\end{array}$ \\
\hline Eigenvalues & 0.031 & 0.024 & 0.003 & 0.002 & 0.070 \\
$\begin{array}{l}\text { Species-environment correlations } \\
\text { Cumulative percentage variance }\end{array}$ & 0.947 & 0.973 & 0.943 & 0.822 & \\
$\quad$ & & & & & \\
$\quad$ of species data & & & & & \\
$\quad$ of species-environment relation & 50.0 & 89.5 & 94.7 & 98.6 & \\
Sum of all unconstrained eigenvalues & & & & & 0.070 \\
Sum of all canonical eigenvalues & & & & & 0.061 \\
Temperature & $-0.7670^{* * *}$ & $-0.5370^{*}$ & 0.1789 & -0.0472 & \\
Relative humidity & 0.3175 & $0.8500^{* * *}$ & -0.2928 & 0.0490 & \\
Wind speed & 0.4180 & 0.2695 & -0.2882 & 0.4496 & \\
Dew point & $-0.8930^{* * *}$ & -0.2571 & 0.1424 & -0.0971 & \\
Rainfall & 0.2035 & $0.6079 *$ & -0.3618 & -0.0144 & \\
Wind direction & -0.2366 & 0.3254 & 0.2996 & $0.5390^{*}$ & \\
\hline
\end{tabular}

Significance levels: * $\mathrm{P} \leq 0.05, * * \mathrm{P} \leq 0.01, * * * \mathrm{P} \leq 0.005$ 


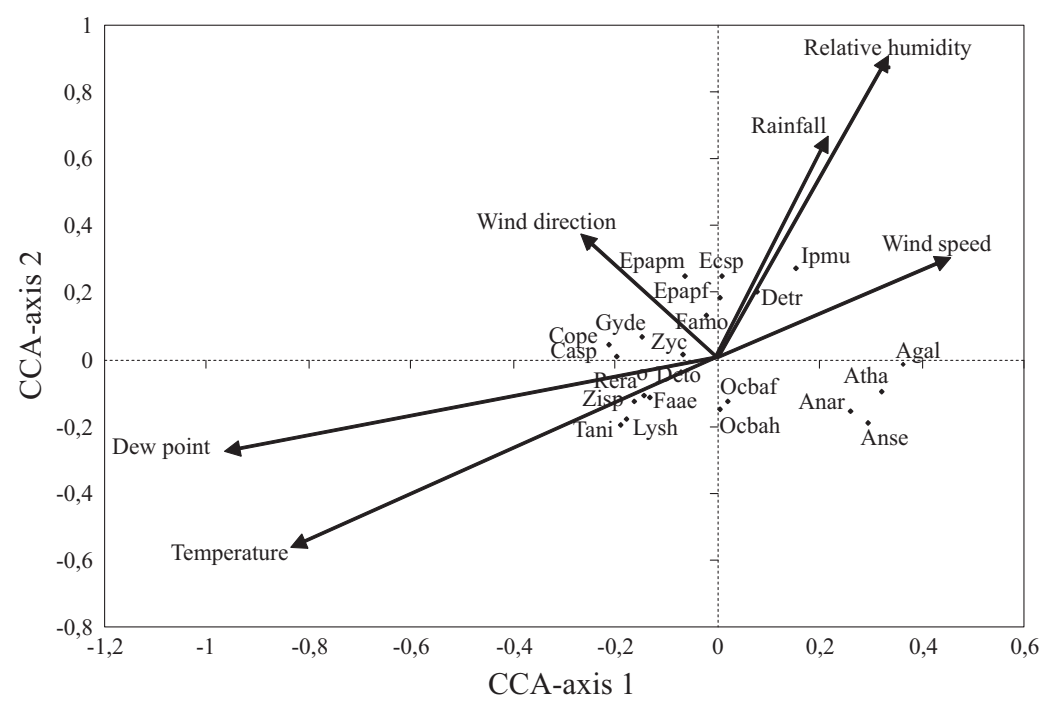

Fig. 4. CCA biplots of the twenty species represented by points and environmental variables indicated by arrows. The species are abbreviated to the first two letters of both genus and species. The fifth letter in E. aphylla and O. baccatus: $\mathrm{m}$ - male, f-female and h-hermaphrodite.

low gradient of temperature and dew point. Two species were significantly associated with wind direction, both of them characterized by having separate sex forms, i.e., male and female individuals, E. aphylla, and female and hermaphrodite individuals, $O$. baccatus.

In the year 2004, the highest Shannon diversity index (H') of flowering phenology for the study species (2.63) was achieved in April, followed by March, May and then February, with $\mathrm{H}^{\prime}$ values $2.58,2.48$ and 2.13, respectively (Figs. 5a, b). Alternatively, the lowest values of $\mathrm{H}^{\prime}$ were achieved in the dry months: July (0.6) and August (0.97) in the year 2006. During the remaining months, values of H' ranged between 1.09 (September 2006) and
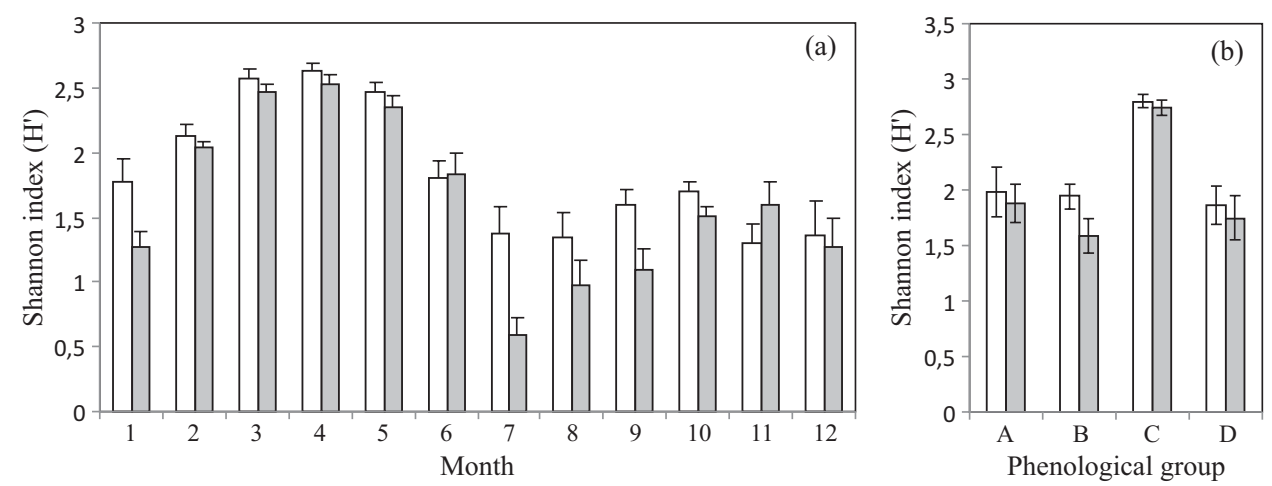

Fig. 5. Shannon diversity index $\left(\mathrm{H}^{\prime}\right)$ of flowering phenology of (a) twelve months and (b) phenological groups in each of two years, 2004 (white column) and 2006 (grey column). Calculations based on the number of flowering individuals. Vertical bars are the standard deviations. Phenological groups: A - winter, B - autumn, C - spring, D - summer flowering. 
1.79 (June 2006). The diversity of flowering phenologies was higher in all months through 2004 than 2006, except in June and November.

In a comparison of flowering phenology at the level of phenological groups, the $\mathrm{C}$ species group, representing spring reproduction, attained the highest $\mathrm{H}^{\prime}$ values through 2004 and 2006 (2.8 \pm 0.63 and 2.74 \pm 0.72 , respectively). The lowest values were attained in group D (dry season) reproduction through 2004 (1.86 \pm 0.17$)$ and group B (autumn season) through 2006 (1.58 \pm 0.15$)$. Phenological group A (winter flowering species) attained intermediate values through $2004(1.99 \pm 0.22)$ and $2006(1.88 \pm 0.16)$.

\section{Discussion}

For plant phenology in desert Wadi ecosystems, plants' responses may involve phenological niche differentiation in space and time, which explains the phenological diversity in desert plants. The twenty study species have demonstrated a complex temporal phenological behaviour. The different plant phenological groups, plus the particular (bimodal) trend of $O$. baccatus, represent an array of phenological niche differentiation according to the time of flowering of most individuals in the different locations of Wadi Degla. The diversity of flowering phenology was higher in spring than in summer, suggesting greater synchrony among the flowering periods of most of the study species in spring. This phenological niche differentiation around the year is subject to seasonally variable biotic and abiotic factors and agrees with the observations of OPLER et al. (1980) in tropical forests, and MARQues et al. (2004) in subtropical forests, who reported on the different phenological patterns according to plant life forms and rainfall events. Adaptive phenology is considered an important reproductive strategy in arid deserts, where many plant species effectively 'escape' from drought in one way or another (WARD 2009).

Biotic factors potentially driving plant phenology include physiological and morphological adaptations for the utilization of resources (RATHCKE and LACEY 1985, PAVON and BRIONES 2001), competition for pollinators or pollinator attraction, and competition for seed dispersers (LOBO et al. 2003), and the avoidance of herbivory (COLEY and BARONE 1996). On the other hand, significant environmental factors such as temporal variations in rainfall (OPLER et al. 1976), changes in water level sequestered by plants (BORCHERT 1994), changes in temperature (PFEIFER et al. 2006), photoperiod (RIVERA et al. 2002), irradiance (HAMANN 2004) and sporadic or 'accidental' climatic events (KASSAS 1966, SAKAI et al. 1999) have all been reported as key factors affecting the phenological niche differentiation of populations and communities.

Plant species belonging to different life forms in particular phenological groups exhibited similar phenological niches. This may be attributed to several different factors, including their occurrence under the same climatic drivers. Moreover, they exhibited the same niche independent of particular physiological and morphological adaptations, or phylogenetics, e.g., group B which flower in summer-autumn included four species in the Chenopodiaceae (AYYAD et al. 1985, Wright and CALDERON 1995, MARQues et al. 2004). Some other species having the same life forms exhibited different phenological niches.

The populations of female and hermaphrodite Ochradenus baccatus included in group $\mathrm{C}$ took different trends in their phenological niche. This may be due to the complex responses to the climatic factors, or other factors such as pollinators, or phylogeny. The par- 
ticular phenological niche of $O$. baccatus includes some individuals flowering over most of the year, with major peaks in spring and autumn (HEGAZY et al. 2011). This pattern in $O$. baccatus was also reported by WOLFE and BURNS (2001) at a wadi located at about $5 \mathrm{~km}$ south of Ein Gedi in Israel. The six species A. alopecuroides, D. tortuosa, D. triradiata, F. aegyptia, $R$. raetam and $Z$. coccineum demonstrated important between-site differences in their phenology. Moreover, most species included in our study showed significant differences in the phenological phases between the two years of observation. Such phenotypic differences in response to environmental cues are an obvious benefit to success in accommodating plant species and differentiation of their flowering times in the different sites of the wadi ecosystem.

As produced from CCA results, more than one factor affected the initiation and duration of the different phenological events, particularly the flowering phase. ABBAD and BENCHAABANE (2004) studied phenology in populations of Atriplex halimus at three locations in western north-Africa, characterized by different climatic conditions. They concluded that phenology was significantly influenced by climatic conditions, where high temperature and rainfall together tended to accelerate formation of flower buds. Phenological events involving reproductive activity in plants are highly affected by temperature and rainfall patterns (JACKSON 1966, INOUYE et al. 2003, LESICA and KITTELSON 2010). Moreover, plants in arid ecosystems respond to the availability of water at particular soil depths and temperatures, accumulated by the location over time. Other factors may also be important. For example, in the present study, the two dioecious and gynodioecious species, E. aphylla and $O$. baccatus were both located on the wind direction gradient, which is considered an important factor influencing their phenological niche.

Topographic features in Wadi Degla may also influence the water availability, with downstream sites receiving more water and developing better soil. The down-stream sites received actual rainfall amounts up to four times as much as the upstream sites, as observed through the tropical rainfall measuring mission, during the recent ten year period (TRMM 2007). PENUELAS et al. (2004) examined the effects of experimental, historical and geographical changes in rainfall and showed highly significant effects on flowering phenology. Their results showed that changes in rainfall and water availability, as an important driver of climate change, can cause complex phenological changes. The width of the wadi bed and its elevation can be considered limiting factors for light incidence, where photoperiod extends for longer periods in the upstream site (width 220-600 m). Soil type plays a role in water availability for plants, where the soil was a mixture of sandy and rocky types in down- and midstream parts but was sandier in the upstream part of a wadi (HASSAN 2002).

GILBERT et al. (1996) studied spatial variation in patterns of selection in a plant-pollinator system in four desert wadis in Sinai, Egypt, and demonstrated significant local (upstream-downstream) specialization in flowering phenology in Alkanna orientalis. They concluded that pollinator behavior was probably responsible for the selection gradient in maternal fitness. Patterns of flowering formed a spectrum, from continuous to very infrequent flowering (NEwSTRom et al. 1994). The diversity of flowering phenology of the different plant species fluctuated around the year where these species use resources in different periods, which relaxes inter-specific competition among co-existing species. There were various phenological niches under the same type of climate. Other factors rather than 
climate may be also responsible for the high flowering phenological disparity. Phytogeographical origin, phylogenetic constraints, structural and architectural traits, and high environmental heterogeneity typical of arid ecosystems seem to be the main drivers of the flowering phenological diversity in Wadi Degla.

In conclusion, plant populations in wadi ecosystems, e.g., Wadi Degla, can be classified with respect to their phenological niche differentiation into an array of patterns: (1) species flowering/fruiting all the year round with two peaks during spring and autumn, e.g., $O$. baccatus; (2) species flowering/fruiting during the winter season including $L$. shawii and $T$. nilotica; (3) species flowering/fruiting during spring, e.g., Z. spinosa, Z. coccineum, C. spinosa and F. aegyptia; (4) species flowering/fruiting during summer, including I. mисronata and $D$. triradiata; and (5) species flowering/fruiting during autumn including $A$. halimus, A. articulata, A. setifera and A. alopecuroides. Temperature, rainfall and relative humidity are the important drivers of phenological niche variations. The weak effect of location on phenology and within-species variation between years, indicate that desert plant phenological niche is principally constrained stronger by phylogenetic character as well as climatic variability than local selective pressure.

\section{Acknowledgment}

We thank the research group \# RGP - VPP - 175 for biodiversity, plant ecology and biotechnology, King Saud University for offering facilities and support of this publication.

\section{References}

Abbad, A., BenchaAbane, A., 2004: The phenological study of Atriplex halimus L. African Journal of Ecology 42, 69-73.

Ågren, J., Ehrlen, J., Solbreck, C., 2008: Spatio-temporal variation in fruit production and seed predation in a perennial herb influenced by habitat quality and population size. Journal of Ecology 96, 334-345.

Augspurger, C. K., 1983: Phenology, flowering synchrony and fruit set of six neotropical shrubs. Biotropica 15, 257-267.

Ayyad, M., Abdel-RaziK, M., Ghali, N., 1985: On the phenology of desert species of western Mediterranean coastal region of Egypt. International Journal of Ecological and Environmental Science 9, 169-183.

Borchert, R., 1980: Phenology and ecophysiology of tropical trees: Erythrina poeppigiana O. F. Cook. Ecology 61, 1065-1074.

BORCHERT, R., 1994: Soil and stem water storage determine phenology and distribution of tropical dry forest trees. Ecology 75, 1437-1449.

Boulos, L., 1999-2005: Flora of Egypt, 1-4. Al-Hadara Publishing, Cairo.

CAP, 2002: Community analysis package: A program to search for structure in ecological community data. Pisces Conservation Ltd., Lymington, Hampshire, UK.

Coley, P. D., BARone, J. A., 1996: Herbivory and plant defenses in tropical forests. Annual Review of Ecology and Systematics 27, 305-335. 
EL-ADAwy, H. A. A., 2011: Variation of population dynamics and phenology of desert plant communities. PhD Thesis, Cairo University.

El-Gamal, M. H., El-Adawy, H. A. A., GaAd, M. A., 2008: Developing renewable groundwater resources in arid lands, Eastern Desert of Egypt, Wadi Degla. Modeling Tasks 3, 29-32.

GHAZANFAR, S. A., 1997: The phenology of desert plants: a 3-year study in a gravel desert wadi in northern Oman. Journal of Arid Environments 35, 407-417.

Gilbert, F., Willmer, P., Semida, F., Ghazoul, J., Zalat, S., 1996: Spatial variation in selection in a plant-pollinator system in the wadis of Sinai, Egypt. Oecologia 108, 479-487.

Goulart, M. F., Filho, J. P. L., Lovato, M. B., 2005: Phenological variation within and among populations of Plathymenia reticulata in Brazilian Cerrado, the Atlantic forest and transitional sites. Annals of Botany 96, 445-455.

Gunster, A., 1994: Phenological niches of coexisting serotinous plants of the Namib Desert. Journal of Tropical Ecology 10, 531-544.

HAMAnN, A., 2004: Flowering and fruiting phenology of a Philippine submontane rain forest: climatic factors as proximate and ultimate causes. Journal of Ecology 92, 24-31.

Hassan, L. M., 2002: Plant life in the Digla Conserved Area, hyperarid desert, Egypt. Online Journal of Biological Science 2, 533-537.

Hegazy, A. K., 1990: Population ecology and implications for conservation of Cleome droserifolia: a threatened xerophyte. Journal of Arid Environments 19, 269-282.

Hegazy, A. K., EeSA, N. M., 1991: On the ecology, insect seed-predation, and conservation of a rare and endemic plant species: Ebenus armitagei (Leguminosae). Conservation Biology 5, 317-324.

Hegazy, A. K., Lovett-Doust, J., El-Adawy, H. A. A., 2011: Size- and season-related sex expression and reproductive performance in gynodioecious Ochradenus baccatus Delile (Resedaceae), at Wadi Degla, Egypt. Flora 206, 1002- 1011.

HILL, M. O., 1979: TWINSPAN-A FORTRAN Program for arranging multivariate data in an ordered two-way table by classification of the individuals and attributes. Section of Ecology and Systematics; Cornell University. Ithaca, NY.

Hudson, I. L., Keatley, M. R., 2010: Phenological research, methods for environmental and climate change analysis. Springer, New York.

Inouye, D. W., SaAvedra, F., Lee-YAnG, W., 2003: Environmental influences on the phenology and abundance of flowering by Androsace septentrionalis (Primulaceae). American Journal of Botany 90, 905-910.

JACKSON, M. T., 1966: Effects of microclimate on spring flowering phenology. Ecology 47, $407-415$.

Kassas, M., 1966: Plant life in deserts. In: Hills, E. S. (ed.), Arid lands, 145-180. Methuen, London.

Lobo, J. A., Quesada, M., Stoner, K. E., Fuchs, E. J., Herrerias-Diego, Y., Rojas, J., SABORIO, G., 2003: Factors affecting phenological patterns of bombacaceous trees in seasonal forest in Costa Rica and Mexico. American Journal of Botany 90, 1054-1063. 
Hegazy A. K., Alatar A. A., Lovett-Doust J., El-Adawy H. A.

Ludwig, J. A., REYNOLDS, J. F., 1988: Statistical ecology: a primer on methods and computing. Jon Wiley and sons, New York.

Marco, D. E., CAlvino, A. A., PAez, S. A., 2000: Patterns of flowering and fruiting in populations of Larrea divaricata in dry Chaco (Argentina). Journal of Arid Environments 44, 327-346.

Marques, M. C. M., Roper, J. J., Salvalaggio, A. P. B., 2004: Phenological patterns among plant life-forms in a subtropical forest in southern Brazil. Plant Ecology 173, 203-213.

Newstrom, L. E., Frankie, G. W., BAKer, H. G., 1994: A new classification for plant phenology based on flowering patterns in lowland tropical rain forest trees at La Selva, Costa Rica. Biotropica 26, 141-159.

Opler, P. A., Frankie, G. W., BAKER, H. G., 1976: Rainfall as a factor in the release, timing, and synchronization of anthesis by tropical trees and shrubs. Journal of Biogeography 3, 231-236.

Opler, P. A., Frankie, G. W., BAKer, H. G., 1980: Comparative phenological wet and dry studies of treelet and shrub species in tropical forest in the lowlands of Costa Rica. Journal of Ecology 68, 167-88.

PAvón, N. P., Briones, O., 2001: Phenological patterns of nine perennial plants in an intertropical semi-arid Mexican scrub. Journal of Arid Environments 49, 265-277.

Penuelas, J., Filella, I., Zhang, X., Llorens, L., Ogaya, R., Lloret, F., Comas, P., Estiarte, M., Terradas, J., 2004: Complex spatiotemporal phenological shifts as a response to rainfall changes. New Phytologist 161, 837-846.

Pfeifer, M., Heinrich, W., JetschKe, G., 2006: Climate, size and flowering history determine flowering pattern of an orchid. Botanical Journal of the Linnaean Society 151, 511-526.

RATHCKe, B. J., LACEY, E. P., 1985: Phenological patterns of terrestrial plants. Annual Review of Ecology and Systematics 16, 179-214.

Rivera, G., Elliott, S., Caldas, L. S., Nicolossi, G., Coradin, V. T. R., Borchert, R., 2002: Increasing day-length induces spring flushing of tropical dry forest trees in the absence of rain. Trees 16, 445-456.

Sakai, S., Momose, K., Yumoto, T., Nagamitsu, T., Nagamasu, H., Hamid, A. A., NAKASHizUKA, T., InOUe, T., 1999: Plant reproductive phenology over four years including an episode of general flowering in a lowland dipterocarp forest, Sarawak, Malaysia. American Journal of Botany 86, 1414-1436.

SEGHIERI, J., SimIER, S., 2002: Variations in phenology of a residual invasive shrub species in Sahelian fallow savannas, south-west Niger. Journal of Tropical Ecology 18, 897912.

Shaltout, K. H., 1987: Pattern, phenology and sex ratio of Egyptian Thymelaea hirsuta populations. Vegetatio 72, 67-73.

Stone, G. N., Willmer, P., Rowe, J. A., 1998: Partitioning of pollinators during flowering in an African Acacia community. Ecology 79, 2808-2827.

TRMM 2007: Tropical rainfall data. http://disc2.nascom.nasa.gov/ Giovanni/tovas/. Retrieved February 28, 2012. 
Ter BraAK, C. J. F., Šmilauer, P., 2002: CANOCO reference manual and CanoDraw for Windows. User's guide: software for canonical community ordination. Version 4.5. Microcomputer Power, Ithaca, NY, USA.

Vitasse, Y., Delzon, S., Bresson, C. C., Michalet, R., Kremer, A., 2009: Altitudinal differentiation in growth and phenology among populations of temperate-zone tree species growing in a common garden. Canadian Journal of Forest Research 39, 12591269.

WarD, D., 2009: The biology of deserts. Oxford University Press, Oxford.

Wolfe, L. M., BuRns, J. L., 2001: A rare continual flowering strategy and its influence on offspring quality in a gynodioecious plant. American Journal of Botany 88, 1419-1423.

Wright, S. J., CAlderon, O., 1995: Phylogenetic patterns among tropical flowering phenologies. Journal of Ecology 83, 937-948. 